\title{
SOME CLINICAL OBSERVATIONS OF THRESHOLD \\ SHIFT ON SUSTAINED TONE
}

\author{
By \\ K. OWADA, K. KOGA, A. TAKASAKI AND K. KIMURA \\ From the Depertment of Oto-Rhino-Laryngology of Keio University, \\ School of Medicine (Director: Prof. Nishihata)
}

Slyghtly superliminal sustained tone was given by an ordinary pure tone audiometer with $5 \mathrm{db}$ step attenuator, the threshold shift was measured at $1000 \mathrm{cps}$ and $8000 \mathrm{cps}$. Normal persons, and those of perceptive deafness, conductive deafness and the patients who were treated with Streptomycin were subjected to this test.

The results were as follows:

1) In patients of perceptive deafness, the threshold shift on sustained tone was observed. It was more distinct at $8000 \mathrm{cps}$ than at $1000 \mathrm{cps}$.

2) Two types of the threshold shift were observed.

Type I: Rapid threshold shift (over $20 \mathrm{db}$ in 1 minute).

Type II : Slow threshold shift (less than $15 \mathrm{db}$ in 3 minutes). This type was observed not only in perceptive deafness but also in conductive deafness.

3) It has been reported that hearing impairment caused by administration of Streptomycin includes retro-labyrinthine deafness. But no difference was observed between the threshold shift of Streptomycin deafness and other perceptive deafnesses.

4) $50 \%$ of the patients who had been given Streptomycin causing no hearing impairment revealed threshold shift on sustained tone. This group belongs to Type $\mathbb{I}$.

5) In a case of acute perceptive deafness which showed rapid threshold shift, " disappearance of this phenomenon was observed in proportion to the restoration of the hearing acuity.

\section{連続音による閾値上昇の臨床的観察}

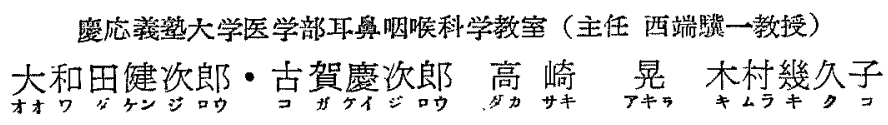

\section{緒 言}

1952 年 Reger が Békésy 型 Audiometer を用い

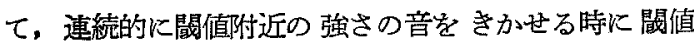
の上戒をきたするのを Temporaly Threshold Shift (TTS) と唱えてから, TTS は広く観察されるように なつた。 Dix 等はこの現象は intensity と loudness の閣係が recruitment 現象と逆であることから, rel一 apse phenomenon と呼び, 末梢器の pathological adaptation に上ると考党た。

TTS の検查の多くは Békésy 型の自記 Audiome- ter を用い，周波数を固定し，時間的に連続的に闇値を 測定し，時間の経過につれて起る閾値の変化を記録して いる.

Dix 等はこの現象が感音性難聴の際に起るので，伝 音性難聴との鑑別に役立つと述へている・我が国に招い ても志井田，立木（孝）等により自記オージォメ一タに よる検查が行われ，田口は間值の上昇を示するのは後迷 路性の疾患飞多いと報告した。

我々は Békésy 型のオージオメータタ? 用いずに JIS 規格によつたオージオメータをを用いて，一定の強さの最 
小可聴值をきかせ，䦨值の変化を測定した．Békésy 型の固有周波数德闇自記法では，音の強さが時間とつも に增大あるいは減少するので，一定の強さの音に対する 感覚ではなく，等しい感覚になるように強さを変えてい る・即ち变化している音に対する闒値である。

我々が行つた方法は同一つ強さの音を与えた特に閔值 が変化してきこ充なくなる時間を測つている・しかし従 来の報告例つ多くは变化している音に対する闒值である ので, 我々の 测定が違つた意味を持つるのかるしれな いこの方法を用いて，難聴を訴える患者を検查したと ころ，興味ある知見を得たので報告する次第だある。

\section{検查方法}

検查に用いた機械は通常のオージオメータである・先 ら断続上昨法で最小可聴值を求める・最小可聴值が決つ たらその音を時間的に連続してきがせおく，ある時間 経過している中にこの音がきこえなくなる，その時に合 図をさせる・音をきかせてから合図のある迄の時閒を測 り記載する. 合図つ後 5 秒其儘としてから音を $5 \mathrm{db}$ 強 くすると再びきこえてくる、この強さの音を連続してき かせ，再びきこえなくなる迄の時間を測る。このように して音をきがてからきこえなくなる迄の時盟を測り， 音の強さを記録してゆく，音をきかせてから3分以上経 過してきこえている時汢その後の変化はないるのとし た。闒值上舁により音がきこえなくなつた時にはその音 を暫く続けていてもきこえてこないいるし直にきこえる ような脚は閔值变化とは認めないことにした・それでき こえなくなつたと合図して 5 秒間様子を見ることにし た。

この方法は普通の audiometry の後に行い，周波数 は $1000 \mathrm{cps}$ 及び 8000 ะps の2つの音とした。

\section{被検者}

正常聴力者 8 耳, 伝音性難㯖者 14 耳, 感音性難聴者 26 耳 Streptomycin 投与後引者 24 耳である、これ等 の診断は耳鼻咽喉の所見や Audiogram によつてきめ た. Streptomycin 投与後の者走分行た理由は後に述 ベることにする.

\section{測定成績及びその検討}

最小可聴值の测定は $5 \mathrm{db}$ ステップで行つているの で, 求めた最小可聴音はき〉得る最小の音から $1 \mathrm{db}$ 位 大きい音から $4 \mathrm{db}$ 大きい音の場合がある筈である. 從 つて音をきかせて最小可聴值の変化をみる場合汇，1db の音ではきこ光ていた音がきこえなくなつても $4 \mathrm{db} の$ 時炕はきこえているという事むあり得るであるう従つ
て一回の変化，即ち $5 \mathrm{db}$ だけの閖值上昇をきしたるの は閔值変化の中に入れなかつた，成續を较括すると第 1

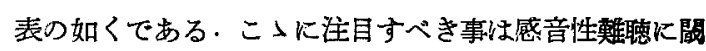

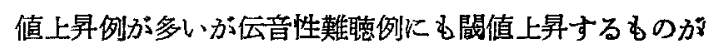
ある・正常者には認められない。

第 1 表

\begin{tabular}{|c|c|c|c|c|c|}
\hline cps & 閾值 & IE & 伝 㩲 & 感 難 & S.M \\
\hline 1000 & $\begin{array}{l}\text { 不变化 } \\
\text { 変 化 }\end{array}$ & $\begin{array}{l}8 \\
0\end{array}$ & $\begin{array}{r}14 \\
0\end{array}$ & $\begin{array}{c}8 \\
5 \\
(38.5 \%) \\
\end{array}$ & $\begin{array}{c}15 \\
9 \\
(37.5 \%)\end{array}$ \\
\hline 3000 & $\begin{array}{l}\text { 不変化 } \\
\text { 変 }\end{array}$ & $\begin{array}{l}8 \\
0\end{array}$ & $\begin{array}{c}9 \\
4 \\
(31 \%)\end{array}$ & $\begin{array}{c}1 \\
12 \\
(93 \%)\end{array}$ & $\begin{array}{c}8 \\
16 \\
(67 \%)\end{array}$ \\
\hline
\end{tabular}

連綄音による閔值上䄯の洔間的変化の状態をみるだめ に第 1 図, 第 2 図を作つた。縦軸は上昇した閶値の值を
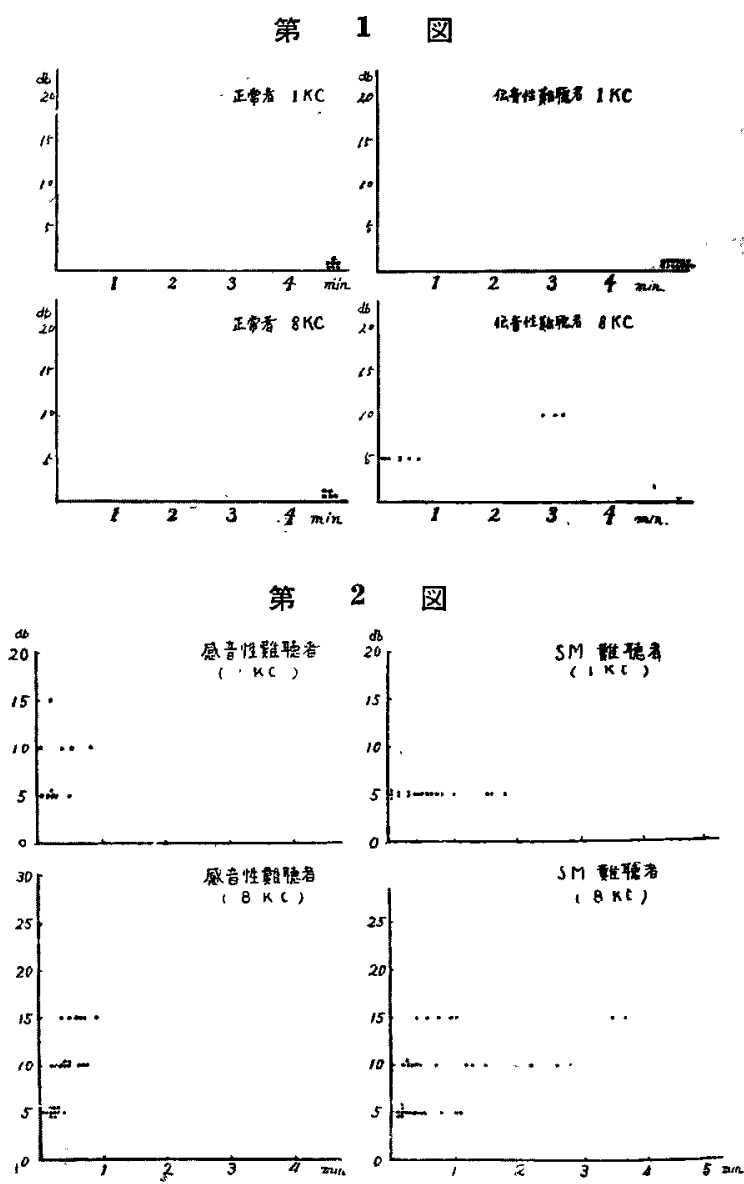
$5 \mathrm{db}$ ステップで取り，横軸には時間を取つてある・例 えば第 1 図で正常者 $1000 \mathrm{cps}$ の例では最小可鯰音をき かせておくと 2 分 48 秒できこえななり， $5 \mathrm{db}$ 大きく したが，この音はその後 3 分経つてもきこえていること を示す 横軸右端の黒点は全く変化しなかつた耳数を示 してある。

この表で明らかなことは，閥值上舁を示す例は感音性 難聴者に多く，全体に見て，1000cps より8000cps で 著明である。

䦪值上年をきたす例は後迷路性難聴に多いといら報告 がちるので，感音性難聴つ中で，後迷路性難聴を伴5と 考觉られる SM 投与による難聴を分けて図示したが， 感音性難聴と蓒べて特に著明な变化を認めなかつた．

Dix 等は一側性難聴者について，患耳閶值上の連 続音をきかせて招いて，正常耳との loudness balance を行5 と第3図の上5に初めは正常耳で $70 \mathrm{db}$ の大き さと等しかつたものが，与えた音の強さは等しいのに 2 分後健耳で $30 \mathrm{db}$ 位の大きさと等しくなつている。

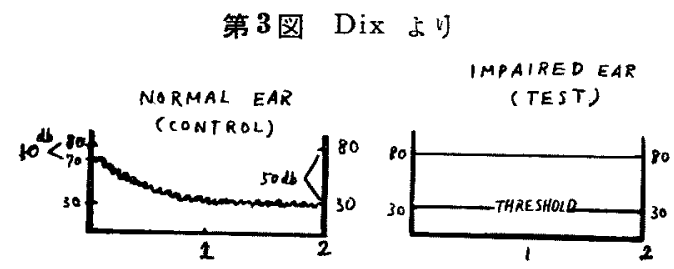

これは患耳の閶值上昇と並行して起る現象である。 同じ耳で音を断続して行えば recruitment 現象が現わ れて loudness balance されたときの患耳の間值上 intensity は健耳のそれより小であるが，連続音では intensity は同じでも患耳の loudness が次第に小と なるため，一見 recruitment 現象が消失したような状 態になるが，更に時間が経つと患耳の intensity に対 する loudness は正常耳のそれより小となり，recruitment 現象と逆になるわけである。 Dix はこれをRelapse phemomenon と云つた.

そして recruitment 現象のある例に多く，感音性難 聴の診断に価值ありとした・しかし我々の方法では伝音 性難聴にも闒値上舁が見られたものがある。

第 1 図, 第2 図を見ると閶值上界の状態に二つの傾向 があることがかかる、第 4 図の如く短時間内に閵值上昇 (1 分間に $20 \mathrm{db}$ 以上)をきた例と徐々に闒值上最 (2 分間に $15 \mathrm{db}$ 以内）をきたす例がある・前者をI型，後 者を项型と呼ら゙ことにする。

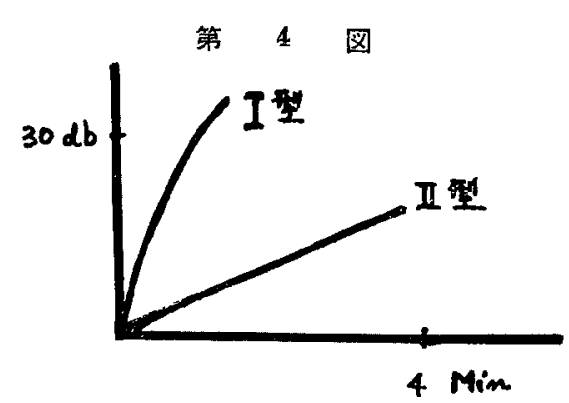

第 1 図，第2 図を見ると，伝音性難德では II 型であ り，感音性難聴及びストマイによるるのはＩ型と爬型が 混つているか゚，I 型はむしろ感音性難聴の力が多い，両 者の意義についてては今後検討を加える積りである.

難聴の状態と型との関保を第 2 表に示した．各型該 当する所に耳数を記入した。

第 2 表

\begin{tabular}{|c|c|c|c|c|c|c|}
\hline & 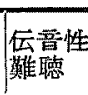 & 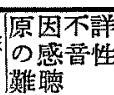 & 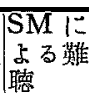 & 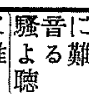 & 腷腫瘍 & 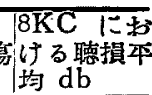 \\
\hline I 型 & & 3 & 5 & 2 & 3 & 52 \\
\hline II 型 & 3 & 3 & 18 & & & 40 \\
\hline
\end{tabular}

I 型と II 型との相違が聴力損失值に関你があるのでは ないかと考えられるので, $8000 \mathrm{cps}$ での聴力損失值の平 均值を求めてみた。これ第 2 表に記載したが，I型に 属するものは II 型に比し 聴力損失值が大きい势のが多 …第2表学見ると急激上昇型が必ずしも後迷路性に多 いとも云えない，且つI型，正型を含わた閔値上昇は後 迷路性と云らこともなさそうである・I型が伝音性難聴 にも現われることは更に検討を要することであるう。

以前に我々が行つた報告で猫に扔ける SM の聴器障 碍の実験を行つたが，その時に末梢聴器障碍の現われる 前に Nucl. vent. 1. cocholeae の神経細胞飞退行变性 が見られた例があつたので，SM 投与後早期に未だ雚 聴の現われる前にもこのような現象があるのではないか と思い, 次の検查を行つた。

$\mathrm{SM}$ 投与患者で聴力検查を行い，測定の 各周波数に 招いて難聴の発現していない耳について同様の検查を行

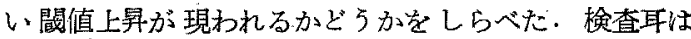
10 耳である、その結果は第5 图の如くであつて，その

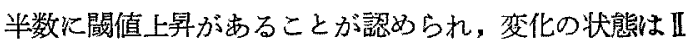
型が多かつた。

この闇值上閶をした例が後になつて難聴を起すかど 
第 5 図
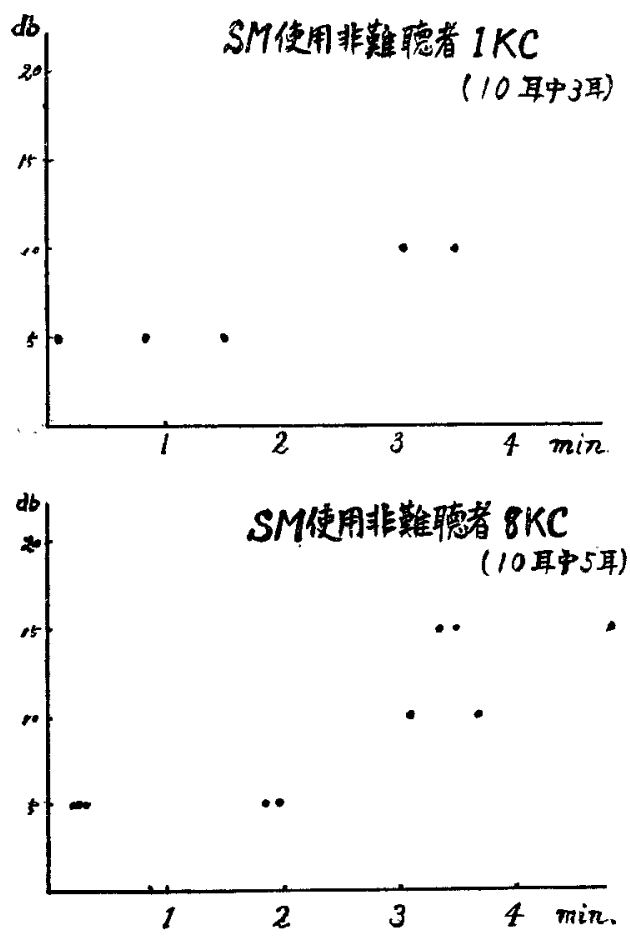

5かを観察している.もしそ5であるならば，閶值変化 が SM による難聴の早期現象として役立つであるう．

间值上昇の状熊が聴力とどのような関係にあるかを次 の症例につい・て観察した・急性感音性難聴には聴力の回 復する例があるので，この症例について聴力の変化と〉 もと閥值の上氟の状態がどう变るかを追求しだ。

患者は35才男子で㔖然一侧性の難聴となつた。眩量 等の訴党はなかつた・Audiogram は第6図わ如くで， 気導骨導ともに低下゙し Balance 法による recruitment

第 6 図

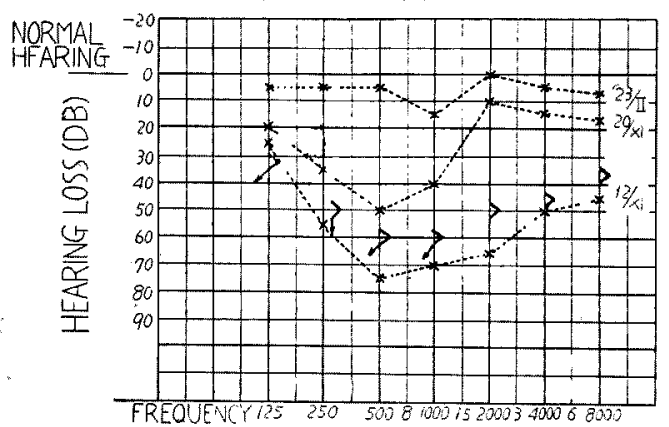

陽性で急性感音性難聴と猃断された。この時連続音によ る間值変化をしらべると第7 図の如くであり，著しい闒 值上武を示し，I型であつた。この例は治潦により聴力

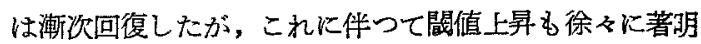
でなくなつている. 即ち聴力の回復とつるに閔値上昇も なくなつてきているこの例で見ると型を示す闘值上 舁も聴力の回復と〉もに消失するものであることがわか つたここの現象が迷路性か後迷路性かはこの例では明ら かにし難いが recruitment は陽性であつた。

第7图連続晋による闌值上暴

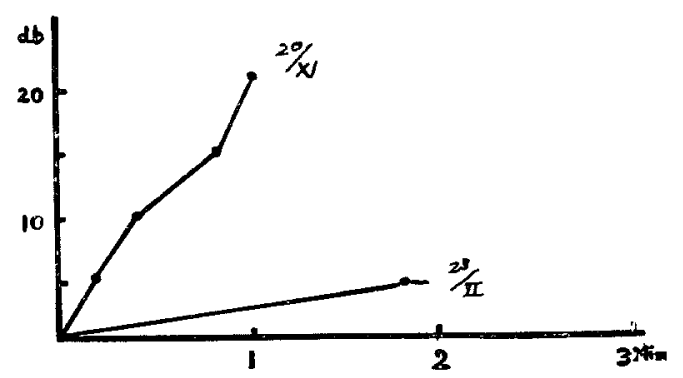

SM を使用した患者でこの現象が見られたので，猫 を用いSM の注射によつて聴器障碍を起させた後, 蝸 牛電気反応を用いて蝸牛からこのような現象が起るかど らかを実験した・実験の詳細に関しては省略するが 6 頭 の $2 \mathrm{~kg}$ 内外の猫を用い, $250 \mathrm{mg} / \mathrm{kg}$ を約 1 力月間筋注 したむのを用いた，電極は正円空に当て，雬科用セメン トで前壁に固定し，先つ 250 8000cps の各音について 電位を求め，障碍された 4 8000 cp と赫いて長時間連 続音をきかせてみたが，5分間の観祭ではどの例でも電 位变化はなかつた。この現象がいかなる部分から起るの か今後の課題としたい、

\section{結語}

オージオメータを用いて最小可聴值音を連続してきか せて, 閔値の上昇の状態を検討した. 被検者は正常者, 伀音性難聴者, 感音性難聴者,ストマイによる聴力障碍 者等で，68耳である. 测定周波数は $1000 \mathrm{cps}, 8000 \mathrm{cps}$ とした。

結果は連続音による䦪值上界は感音性難聴に多く， $1000 \mathrm{cps}$ より $8000 \mathrm{cps}$ の方が大きい，又閔值上昇に 2 つの型があることを見出した・即ら間值上鼎か゚ 1 分以内 に急激に起る例を】型とした。2〜3分の間に徐々に起 る例を开型とした。I型は感音性難聴に多く，後迷路性 難聴に特有と断定はできないが，聴力障碍の大なる例に 
多い，I型は感音性難聴のみならず伝音性難聴にも見ら れることがある.正常者ではこのような例はない， SM. による難聴は中枢性難聴を含むと考えらるが，その他 の感音性難聴との間に特に差を譛めなかつた・页 $\mathrm{SM}$ 注射中の患者で難聴の現われない例でも半数において闖 值上昇を現わしII型であつた。

急性感音性難聴で，連続音による間值上昇があつた （I型）患者では聴力の回復と〉るにこの現象む消失し 正常に戾つた。.

連続音による闆值上昇は一般の感意性難聴に多いが， 伝音性難聴にも認められ，又難聴の発現してない例にる 認められる. 更に検討を加点らるぺき問題であるう。

\section{文献}

1) S.N. Reger and C.M. Kos: Clinical measurement and implication of recruitment. Annals of Oto Rhino Laryng. Vol. $61 ; 810,1952 . \quad 2)$ M.R.
Dix and S.D. Hood: Modern developments in pure tone audiometry and their application to the clinical diagnosis of end-organ deafness. Journal of Laryng. \& Otol. Vol. 67, 343, 1953.

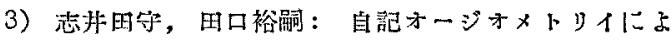
る閶值聴力の観察, 耳喉, 27 癹, 241 頁, 炤 30.4 ). 立木孝：自記オージオメーターの䠛棈的応用に関する

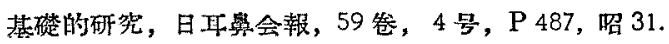

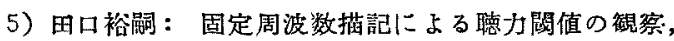
耳喉, 29 卷, 688 頁, 炤 32 .

(終りに恩即西端教授の御校閔を深謝する)

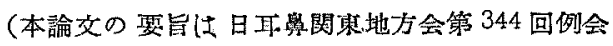
で㵦べた)

（原程到意=炤和 32.3 .5 日） 